\title{
Replacement of Fish Meal with Moringa oleifera Leaf Meal (MOLM) and its Effect on Growth Performance and Nutrient Digestibility in Labeo rohita Fingerlings
}

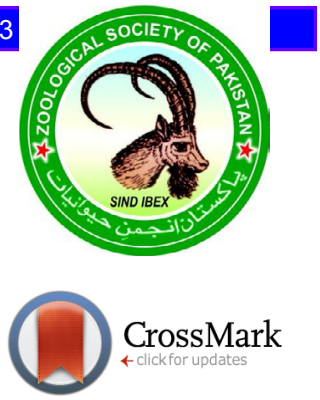

\author{
Syed Makhdoom Hussain ${ }^{1, *}$, Muhammad Zubair ul Hassan Arsalan', \\ Arshad Javid $^{2}$, Abdullah Ijaz Hussain ${ }^{3}$, Nosheen Aslam ${ }^{4}$, Qasim Ali ${ }^{5}$, Majid Hussain ${ }^{6}$, \\ Muhammad Masoom ul Hassan Rehan ${ }^{7}$, Muhammad Mudassar Shahzad ${ }^{1,8}$, \\ Anam Khalid ${ }^{1}$ and Danish Riaz ${ }^{1}$
}

${ }^{1}$ Fish Nutrition Lab, Department of Zoology, Government College University, Faisalabad ${ }^{2}$ Department of Wildlife and Ecology, University of Veterniry and Animal Sciences, Lahore

${ }^{3}$ Natural Product and Synthetic Chemistry Lab, Department of Chemistry, Government College University, Faisalabad

${ }^{4}$ Department of Biochemistry, Government College University, Faisalabad

${ }^{5}$ Department of Botany, Government College University, Faisalabad

${ }^{6}$ Department of Zoology, University of Gujrat, Gujrat

${ }^{7}$ Department of Biochemistry, University of Agriculture, Faisalabad

${ }^{8}$ Department of Zoology, Division of Science and Technology, University of Education, Township Campus, Lahore

\section{A B S T R A C T}

A 70-day feeding trial was conducted to evaluate the effects of MOLM on growth performance and nutrient digestibility in $L$. rohita fingerlings. MOLM was added in the diet by replacing fish meal at the levels of $0 \%, 10 \%, 20 \%, 30 \%$ and $40 \%$. Triplicate tanks were used for each treatment having 15 fingerlings. These fingerlings fed at the rate of $5 \%$ of live wet weight. Chromic oxide as an inert marker was also added in the diets. Feces from each tank were collected twice a day to estimate the nutrient digestibility parameters. The maximum weight gain (304\%) and minimum FCR (1.33) values were noted at $10 \%$ replacing level for above mentioned diet showed that fish was in more healthy condition as compared to control ( $0 \%$ MOLM) and other test diets. Digestibility coefficients for MOLM based diet at $10 \%$ replacement level of fish meal, increased $13.98 \%, 14.29 \%$ and $10.52 \%$ for crude fat, crude protein and supposed gross energy when compared to control diet, respectively. The next higher growth performance and nutrient digestibility values were observed at $20 \%$ replacement level based diet. It was concluded that the $10 \%$ replacement level of fish meal with MOLM is optimum which release adequate amount of chelated nutrients for maximum growth performance of $L$. rohita fingerlings.

\begin{tabular}{l} 
Article Information \\
Received 16 August 2016 \\
Revised 25 March 2017 \\
Accepted 18 April 2018 \\
Available online 07 August 2018 \\
Authors' Contribution \\
SMH supervised the project and \\
provided the facilities for the research. \\
MZHA collected the data and \\
compiled and analyzed the results. \\
AJ helped in statistical analysis. \\
AIH analyzed the nutrients. NA did \\
biochemical analysis. QA analyzed \\
the data statistically and interpreted \\
the results. MH collected the samples. \\
MMHR prepared the manuscript. \\
MMS helped in research work and \\
collection of growth data. AK assisted \\
in collection of fecal matter. DR \\
conducted feeding trials. \\
Key words \\
\hline Moringa oleifera leaf meal, Growth \\
performance, Nutrient digestibility, \\
Labeo rohita.
\end{tabular}

\section{INTRODUCTION}

G lobal fish demand has been increased due to rapid increase in fish consumption and world population growth. The worldwide population is estimated to be increased up to 9 billion in 2050. Almost 50\% more food will be required to meet the demand of rapidly growing population (Diana et al., 2013). The aquaculture expansion will help to meet the growing fish demand and also will

\footnotetext{
* Corresponding author: drmakhdoom90@gmail.com 0030-9923/2018/0005-1815 \$ 9.00/0

Copyright 2018 Zoological Society of Pakistan
}

relieve pressure on steadily declining capture fisheries (Tacon and Metian, 2013). Fishmeal is an exceptional protein source in aqua-feeds due to its high palatability digestibility, and excellent composition of minerals, fatty acids and essential amino acids (Olsen and Hasan, 2012). Moreover, in previous three decades fish meal prices have also increased in real terms and are expected to be increased further with continuous growth in demand. This rapid increase in fish oil and fishmeal prices may have negative effect on the commercial aquaculture projects (Naylor et al., 2000). Fishmeal has also been used as major feed component in intensive livestock farming, i.e. pork and poultry. However, aquaculture sector is utilizing greater 
share of global fishmeal resource, as alternates for poultry and livestock are more easily available (Bostock et al., 2010). Due to the finite supply and rising cost of fishmeal, aquaculture feed industry and research institutions have conducted a large number of studies to reduce dependency of aquaculture industry on fishmeal (Tacon et al., 2006; Rana et al., 2009). A shift towards partial replacement of animal and plant proteins as protein source in fish feed is widely accepted in commercial aquaculture (Naylor et al., 2000). In order to attain economically unassailable, environment friendly and viable production, researchers are evaluating unconventional protein sources predominantly from plant by-products such as leaves, seeds and other agricultural feed stuff due to their high protein contents (Richter et al., 2003; Abo-State et al., 2014). Plant based ingredients used in aquaculture feeds are required to possess certain nutritional values such as low level of starch, fibers and anti-nutrients. There must be present relatively high protein contents, nutrient digestibility and palatability with favorable amino acid profile. The variety of plants and their ingredients in aquaculture feeds includes canola, barley, peas/lupins, corn, cottonseed, wheat and soybeans has been used. Overall, the potential of replacing plant-based proteins into aquaculture feeds is very high but depends upon their availability, relative price and palatability for cultured species (Naylor et al., 2009). Plant-based proteins are ideal and probably will continue to be the main substitute of fishmeal in aquaculture diets (Gatlin et al., 2007; Olsen and Hasan, 2012).

Moringa oleifera is one of the potential protein sources for inclusion in aquaculture diets (Chiseva, 2006). Basically it is the most widely cultivated plant species belonging to genus Moringa, the only genus of family Moringaceae containing high crude protein $(251 \mathrm{~g} / \mathrm{kg} \mathrm{DM})$ in the leaves, with low content of tannins and other anti-nutritional compounds (Nouala et al., 2006). Moringa leaves are rich in crude protein content which varies from 25\% (Makkar and Becker, 1996) to $32 \%$ (Soliva et al., 2005). Due to high proportion of pepsin soluble nitrogen $(82-91 \%)$ a high proportion of this protein is potentially available for digestion due to a high amount of pepsin soluble nitrogen and low proportion (1-2\%) of acid detergent insoluble protein, the protein is potentially available for digestion (Makkar and Becker, 1996). The protein comprises high levels of sulphur containing amino acids and compares well with soybean, which is usually considered as a source of high quality plant protein (Francis et al., 2001). Its crude lipid contains $\mathrm{n}-3$ fatty acids in the form of linolenic acid which account for about $67 \%$ of total fatty acids (Soliva et al., 2005). The leaves of Moringa plant are significant source of carotenoids, minerals, ascorbic acid and iron. Earlier studies have shown that $M$. oleifera is considered as promising source of protein for inclusion in fish diets at low levels (Ayotunde et al., 2011). Leaves of Moringa are the best source of high amount of nutrients such as crude protein, crude fat and gross energy etc. (Bosch, 2004; Grubben and Denton, 2004). It is also potential protein substitute in fishmeal based diets which can minimize the use of fishmeal in aquaculture due to its nutritional value of total soluble protein and high pepsin. Because of the favorable amino acid profile and wide availability throughout the tropical and subtropical regions, Moringa leaves can be regarded as a potential feed component of fish diet to make aquaculture production cost effective (Tagwireyi et al., 2014).

Labeo rohita is one of the most important major carp species cultured in Pakistan on large scale. It is grown under poly-culture system with the other species of major and Chinese carps (Hussain et al., 2011). Regional culture practices are mostly based on semi-intensive culture systems. No cost effective feed is available to local fish farmers. However, various crude formulations are being used in the form of mesh feeds to further enhance the fish production (Hussain et al., 2015, 2016). Available literature has revealed that $M$. oleifera is under investigation as possible substitution for fish meal in diet of various fish species, however a lesser amount of literature is available on the M. oleifera leaf meal (MOLM) based diets for Indian major carp i.e. L. rohita. Therefore, the present research work is conducted to find out the best and least cost protein sources such as Moringa leaf meal for commercially important $L$. rohita to enhance its production and to overcome the problems of costly fish meal.

\section{MATERIALS AND METHODS}

The present research was conducted to study the effects of varying levels of $M$. oleifera leaf meal based diets on growth performance and nutrient digestibility of L. rohita fingerlings. The experiment was conducted in the Fish Nutrition Laboratory, Department of Zoology, Government College University, Faisalabad.

\section{Fish and experimental conditions}

L. rohita fingerlings were obtained from Government Fish Seed Hatchery, Faisalabad and then kept in V-shaped tanks (designed for the collection of feces with $70 \mathrm{~L}$ water capacity) for two weeks to acclimatize them with experimental conditions. Before the initiation of feeding trial, L. rohita fingerlings were treated with $\mathrm{NaCl}\left(5 \mathrm{~g} \mathrm{~L}^{-1}\right)$ to prevent the fingerlings from ectoparasites and to make it sure that there is no further fungal infection (Rowland and Ingram, 1991). During the period of acclimatization the $L$. rohita fingerlings were provided with the basal diet once 
a day to apparent satiation (Allan and Rowland, 1992). Water quality parameters such as water temperature, $\mathrm{pH}$ and dissolved oxygen were monitored through $\mathrm{pH}$ meter (Jenway 3510), DO meter (Jenway, 970) and electrical conductivity (EC) meter (HANNA: HI. 8633) on daily basis. Aeration ( $24 \mathrm{~h}$ ) was supplied to all the experimental tanks through capillary system.

\section{Processing of Moringa oleifera leaf meal}

Moringa leaves were obtained and soaked overnight in a tank to remove saponins and other water soluble antinutritional factors. A wire mesh was used to drain excess water by placing the leaves on it, and then the soaked leaves were spread on plastic sheets to dry under shade to prevent loss of vitamins through photodynamic damage or oxidation. The dried leaves were threshed from stalks to reduce crude fiber content in the meal. The dried leaves were then subjected to grinding and converted them into a fine powder by the use of a hammer mill (Lab Mill, screen size $0.2 \mathrm{~mm}$ ) and the powder then stored in plastic bags at room temperature.

\section{Experimental design}

M. oleifera leaf meal (MOLM) was used as test ingredient to replace costly fishmeal and formulation of test diets having varying levels of replacement. The feed ingredients were procured from a commercial feed mill and analyzed for chemical composition following standard methods (AOAC, 1995) before the formulation of the experimental diet. The feed ingredients were grinded and sieved to require particle size before formulation of experimental diet (Table I). MOLM was used in the diet formulation by replacing fishmeal at the rate of $0 \%, 10 \%$, $20 \%, 30 \%$ and $40 \%$ and the feed was given to five fish groups which were stocked in water tanks having $70 \mathrm{~L}$ water capacity. There were three replicates each tank having 15 fingerlings used for every treatment. V-shaped tanks were designed especially for the collection of fecal material from water media. Fingerlings were fixed up with $12 \mathrm{~h}$ dark and night period throughout the trial. Total experimental duration was 70 days during which $5 \mathrm{~g}$ feces were collected for proximate analysis from each replicate. MOLM based diets were subjected to comparison with each other and with control diet in relation to determine optimum level of fish meal replacement for different parameters of nutrient digestibility by using completely randomized design (CRD). The trial consisted of two overlapping sections: first section was comprised of assessment of growth performance in terms of weight gain, weight gain (\%) and FCR whereas second section consisted of assessment of the nutrient digestibility coefficient (ADCs) of crude protein, crude fat and gross energy of the control and test diets by using chromic oxide as an inert marker.

Table I.- Ingredient composition (\%) of test diets.

\begin{tabular}{|c|c|c|c|c|c|}
\hline Ingredients & TD-I & TD-II & TD-III & TD-IV & TD-V \\
\hline MOLM* & 0 & $10 / 3$ & $20 / 6$ & $30 / 9$ & $40 / 12$ \\
\hline Fish meal & $40 / 20$ & $34 / 17$ & $28 / 14$ & $22 / 11$ & $16 / 8$ \\
\hline Wheat flour & 34.50 & 30.50 & 26.50 & 22.50 & 18.50 \\
\hline Corn gluten $(60 \%)$ & 16.6 & 16.6 & 16.6 & 16.6 & 16.6 \\
\hline Fish oil & 4.9 & 4.9 & 4.9 & 4.9 & 4.9 \\
\hline Vitamin premix & 1.0 & 1.0 & 1.0 & 1.0 & 1.0 \\
\hline Mineral premix & 1.0 & 1.0 & 1.0 & 1.0 & 1.0 \\
\hline Ascorbic acid & 1.0 & 1.0 & 1.0 & 1.0 & 1.0 \\
\hline Chromic oxide & 1.0 & 1.0 & 1.0 & 1.0 & 1.0 \\
\hline Total & 100 & 100 & 100 & 100 & 100 \\
\hline
\end{tabular}

MOLM*, Moringa oleifera leaf meal; TD-I, test diet-I (control); TD-II, test diet-II (MOLM 10\%); TD-III, test diet-III (MOLM 20\%); TD-IV, test diet-IV (MOLM 30\%); TD-V, test diet-V (MOLM 40\%).

\section{Feed ingredients and formulation of experimental diets}

The feed ingredients which were purchased from a commercial feed mill and then subjected to analysis for chemical composition following AOAC (1995) prior to the formulation of the test diets. The basal diet with sufficient levels of required nutrients for the normal growth of fish was prepared (Table I). All ingredients were subjected to mixing in an electric mixer for $10 \mathrm{~min}$ and fish oil was gradually added during mixing of diet. Chromic oxide (1\%) was incorporated as inert marker. During mixing 10$15 \%$ water was added to feed ingredient to prepare suitable texture (Lovell, 1989). Then these mixed feed ingredients were extruded to form floating pellets $(3 \mathrm{~mm})$ through Lab Extruder (SYSLG30-IV Experimental Extruder). All diets were treated equally in the given extruder to formulate one control diet and four MOLM based test diets. All prepared diets were dried and then stored at $4^{\circ} \mathrm{C}$ until use.

\section{Feeding protocol and sample collection}

The fingerlings of L. rohita were fed on the base of on their prescribed diets at the rate of $5 \%$ of live wet weight. After completing feeding session of two hours, the uneaten diet was drained out from all experimental tanks by opening the valves of the tanks. The tanks then subjected to washing which causes the removal of the particles of diets and then refilled the tanks with water. After that, the fish was restocked in tanks. After two hours intervals, the feces were collected from the fecal collection tube of each tank by opening the valves subsequently. In order to minimize the leaching of nutrients, breakage of fecal strings was prevented. Fecal material from each replicated treatment was oven dried at $60^{\circ} \mathrm{C}$, ground and stored for 
chemical analysis.

\section{Growth study}

During experiment, the fish in each tank were bulk weighed every $15^{\text {th }}$ day to examine the growth performance of L. rohita fingerlings. Weight gain (\%) and feed conversion ratio of experimental fingerlings was evaluated by using standard formulae:

$$
\begin{aligned}
\text { Weight gain } \% & =\frac{\text { Final Weight }- \text { Initial weight }}{\text { Initial weight }} \times 100 \\
\text { FCR } & =\frac{\text { Total dry feed intake }(\mathrm{g})}{\text { Wet weight gain }(\mathrm{g})}
\end{aligned}
$$

\section{Chemical analysis of feed and feces}

The samples of fish feed ingredients, experimental diets and feces were homogenized by using mortar and pestle and were analyzed by standard methods (AOAC, 1995). To determine Moisture contents the samples were oven-dried at $105^{\circ} \mathrm{C}$ for $12 \mathrm{~h}$ whereas crude protein $(\mathrm{N} \times$ 6.25) was determined by micro kjeldahl apparatus. Ether extract (EE) was extracted by petroleum ether extraction method through Soxtec HT2 1045 system; crude fiber (CF) as loss on ignition of dried lipid-free residues after digestion with $1.25 \% \mathrm{H}_{2} \mathrm{SO}_{4}$ and $1.25 \% \mathrm{NaOH}$ whereas ash by ignition at $650^{\circ} \mathrm{C}$ for $12 \mathrm{~h}$ in electric furnace (Eyela-TMF 3100) to constant weight. Total carbohydrates (N-free extract) were calculated by difference i.e., Total carbohydrate $\%=100-(\mathrm{CP} \%+\mathrm{EE} \%+\mathrm{CF} \%+\mathrm{Ash} \%)$. Gross energy digestibility was determined with the help of adiabatic oxygen bomb calorimeter (Parr Instrument Co., Moline, USA).

\section{Digestibility studies}

After the two hours feeding session the water tanks were washed completely to remove the particles of diets and then refilled the tanks with ground water stored in holding tanks at room temperature that was changed manually on daily basis. By opening the valves of each tank subsequently the feces were collected from the fecal collection tube. Fecal material from each replicated treatment was oven dried, then subjected to grinding and stored for chemical analysis. Chromic oxide content was estimated both in diet and feces after oxidation with molybdate reagent using UV-VIS 2001 Spectrophotometer at $370 \mathrm{~nm}$ absorbance (Divakaran et al., 2002). The apparent nutrient digestibility coefficients (ADC \%) of crude protein, crude fat and apparent gross energy for fish were calculated indirectly at the end of the experiment using chromic oxide as inert marker.

ADC $(\%)$ of diets was calculated by the following formula (NRC, 1993):

ADC $(\%)=100-100 \times \frac{\% \text { marker in diet } \times \% \text { nutrient in feces }}{\% \text { marker in feces } \times \% \text { nutrient in diet }}$

\section{Statistical analysis}

Data of nutrient digestibility and growth performance of control diet and test diets were subjected to one-way analysis of variance (ANOVA) (Steel et al., 1996). The differences among means were compared by Tukey's Honestly Significant Difference Test and considered significant at $\mathrm{p}<0.05$ (Snedecor and Cochran, 1991). The CoStat computer software (Version 6.303, PMB 320, Monterey, CA, 93940 USA) was used for statistical analysis.

\section{RESULTS}

The growth performance of $L$. rohita fingerlings fed on MOLM based test diets by replacing the fishmeal with MOLM at $0 \%, 10 \%, 20 \%, 30 \%$ and $40 \%$ is shown in Table II. In the present study MOLM based test diets enhanced the nutritional quality. A significant $(\mathrm{P}<0.05)$ increase in weight gain commensurated with $10 \%$ replacement level after which further increase in replacing level decreased the weight gain of fish. The maximum weight gain $(22.96 \mathrm{~g})$ of L. rohita fingerlings was on MOLM based test diet having $10 \%$ replacement level and this value was significantly different $(\mathrm{P}<0.05)$ from the weight gain on control diet and remaining MOLM replacement levels based test diets. The significant increase in weight gain (\%) was also observed at the same level; that was $349.59 \%$ whereas control diet showed $263.33 \%$.

The minimum weight gain $(16.48 \mathrm{~g})$ was observed at $40 \%$ level of MOLM. The results revealed that weight gain on control diet, 30\% MOLM and 40\% MOLM based diets were statistically similar. Results showed that fish meal replacement at $10 \%$ with MOLM, the weight gain increased as compared to control diet. It was further observed that $30 \%$ and $40 \%$ levels of MOLM replacement could not show significant improvement in growth performance of $L$. rohita fingerlings as compared with fish fed on control diet (MOLM 0\%). The feed intake at control, 30\% and 40\% MOLM replacement levels based diets were significantly lower compared to the value recorded for $10 \%$ MOLM replacement levels based diet. The FCR (1.33) of L. rohita fingerlings was significantly $(\mathrm{P}<0.05)$ improved by feeding on $10 \%$ MOLM replacement level which was significantly different $(P<0.05)$ from other diets including control diet. It showed that MOLM based diets performed well and were converted into flesh in effective way. 
Table II.- Chemical composition (\%) of feed ingredients (dry matter basis).

\begin{tabular}{|c|c|c|c|c|c|c|c|}
\hline Ingredients & $\begin{array}{c}\text { Dry matter } \\
(\%)\end{array}$ & $\begin{array}{c}\text { Crude protein } \\
(\%)\end{array}$ & $\begin{array}{c}\text { Crude fat } \\
(\%)\end{array}$ & $\begin{array}{c}\text { Crude fibre } \\
(\%)\end{array}$ & $\begin{array}{l}\text { Ash } \\
\text { (\%) }\end{array}$ & $\begin{array}{c}\text { Carbohydrates } \\
(\%)\end{array}$ & $\begin{array}{c}\text { Gross energy } \\
\left(\mathrm{kcal} \mathrm{g}^{-1}\right)\end{array}$ \\
\hline Moringa leaf meal & 92.84 & 27.69 & 6.54 & 7.89 & 12.34 & 45.54 & 2.39 \\
\hline Fish meal & 91.63 & 47.25 & 7.23 & 1.12 & 25.56 & 18.84 & 4.67 \\
\hline Corn gluten $60 \%$ & 92.06 & 58.79 & 4.28 & 1.37 & 1.65 & 33.91 & 4.57 \\
\hline Wheat flour & 93.04 & 11.23 & 2.44 & 3.09 & 3.16 & 80.08 & 3.25 \\
\hline Rice polish & 94.86 & 13.48 & 13.17 & 12.70 & 11.09 & 49.56 & 3.59 \\
\hline
\end{tabular}

Table III.- Growth performance of $L$. rohita fingerlings fed varying levels of MOLM based diets.

\begin{tabular}{|c|c|c|c|c|c|c|c|c|}
\hline Diets & $\begin{array}{c}\text { Replacement } \\
\text { levels }\end{array}$ & $\begin{array}{l}\text { Initial weight } \\
\text { (g) }\end{array}$ & $\begin{array}{l}\text { Final weight } \\
\text { (g) }\end{array}$ & $\begin{array}{l}\text { Weight gain } \\
\text { (g) }\end{array}$ & $\begin{array}{c}\text { Weight gain } \\
(\%)\end{array}$ & $\begin{array}{l}\text { Weight gain } \\
\left(\text { (fish }^{-1} \text { day }^{-1}\right) g\end{array}$ & $\begin{array}{l}\text { Feed intake } \\
\left(\text { fish }^{-1} \text { day }^{-1}\right) g\end{array}$ & FCR \\
\hline $\begin{array}{l}\text { Test Diet-I } \\
\text { (Control) }\end{array}$ & MOLM (0\%) & 6.62 & $24.05^{\mathrm{c}}$ & $17.43^{c}$ & $263.33^{c}$ & $0.249^{c}$ & $0.401^{\mathrm{b}}$ & $1.61^{\mathrm{c}}$ \\
\hline Test Diet -II & MOLM (10\%) & 6.57 & $29.52^{\mathrm{a}}$ & $22.96^{\mathrm{a}}$ & $349.59^{\mathrm{a}}$ & $0.328^{\mathrm{a}}$ & $0.435^{\mathrm{a}}$ & $1.33^{\mathrm{a}}$ \\
\hline Test Diet -III & MOLM (20\%) & 6.66 & $26.95^{\mathrm{b}}$ & $20.29^{b}$ & $304.47^{b}$ & $0.290^{\mathrm{b}}$ & $0.424^{\mathrm{a}}$ & $1.46^{\mathrm{b}}$ \\
\hline Test Diet-IV & MOLM (30\%) & 6.62 & $24.06^{\mathrm{c}}$ & $17.45^{\mathrm{c}}$ & $263.68^{c}$ & $0.249^{c}$ & $0.401^{\mathrm{b}}$ & $1.61^{\mathrm{c}}$ \\
\hline Test Diet -V & MOLM (40\%) & 6.61 & $23.09^{\mathrm{d}}$ & $16.48^{\mathrm{c}}$ & $249.24^{\mathrm{c}}$ & $0.235^{\mathrm{c}}$ & $0.399^{\mathrm{b}}$ & $1.70^{\mathrm{c}}$ \\
\hline PSE & & 0.03165807 & 0.26538444 & 0.27609582 & 4.78179767 & 0.00404693 & 0.00418995 & 0.02859662 \\
\hline p-Value & & $0.3798^{\mathrm{ns}}$ & $0.0000 * * *$ & $0.0000^{* * *}$ & $0.0000 * * *$ & $0.0000 * * *$ & $0.0003 *$ & $0.0000 * * *$ \\
\hline
\end{tabular}

PSE, pooled standard error; Means within rows having different superscripts are significantly different at $\mathrm{P}<0.05$. Data are means of three replicates.

Table IV.- Composition of nutrients (\%) in diets of $L$. rohita fingerlings fed varying levels of MOLM based diets.

\begin{tabular}{lccc}
\hline Diets & $\begin{array}{c}\text { Crude protein } \\
(\mathbf{\%})\end{array}$ & $\begin{array}{c}\text { Crude fat } \\
(\mathbf{\%})\end{array}$ & $\begin{array}{c}\text { Gross energy } \\
(\mathbf{\%})\end{array}$ \\
\hline $\begin{array}{l}\text { Test diet-I } \\
\text { (Control) }\end{array}$ & 32.81 & 6.70 & 4.61 \\
$\begin{array}{l}\text { Test diet-II } \\
\text { MOLM (10\%) }\end{array}$ & 32.04 & 6.23 & 4.26 \\
$\begin{array}{l}\text { Test diet-III } \\
\text { MOLM (20\%) }\end{array}$ & 32.04 & 6.21 & 4.25 \\
$\begin{array}{l}\text { Test diet-IV } \\
\text { MOLM (30\%) }\end{array}$ & 32.06 & 6.23 & 4.24 \\
$\begin{array}{l}\text { Test diet-V } \\
\text { MOLM (40\%) }\end{array}$ & 32.10 & 6.23 & 4.25 \\
PSE & 0.08726721 & 0.03555887 & 0.01220205 \\
p-Value & $0.0003 * * *$ & $0.0000 * * *$ & $0.0000 * * *$ \\
\hline
\end{tabular}

PSE, pooled standard error; Means within rows having different superscripts are significantly different at $\mathrm{P}<0.05$. Data are means of three replicates.

The poor value of FCR was noted at $40 \%$ that revealed at this level minimum feed was converted into flesh. Overall, it was observed that L. rohita fingerlings showed the best growth performance in terms of weight gain, weight gain (\%) and FCR when fed on MOLM based diet at $10 \%$ replacement level. The results of growth performance showed that MOLM may be better alternative protein source for fish diets as compared to fish meal which is of high cost.

Analyzed nutrients composition of control diet, test diets and feces are given in Tables IV and V. The data presented in Table $\mathrm{V}$ makes it clear that minimum amount of nutrients such as crude protein, crude fat and apparent gross energy was discharged through feces at $10 \%$ and $20 \%$ levels of MOLM replacement. It is also obvious from the results that in comparison with control diet and remaining MOLM based diets, 10\% level of replacement showed maximum digestibility values for crude protein (74.03\%), crude fat (73.54\%) and gross energy (68.40\%). It was observed that crude protein and gross energy digestibility values at 10\% MOLM replacement level did not differ significantly from 20\% replacement level but varied significantly $(\mathrm{P}<0.05)$ from the control diet and remaining MOLM based diets, whereas, the crude fat digestibility at $10 \%$ and $20 \%$ replacement levels MOLM based diet remained statistically at par. Interestingly, it was also observed that except $10 \%$ and $20 \%$ replacement levels 
MOLM based diet, remaining diets could not show increase in crude protein, crude fat and gross energy digestibility as compared to the control diet (MOLM 0\%) diet (Table VI). Feeds having addition of MOLM upto $30 \%$ and $40 \%$ resulted in decreased nutrient digestibility. In general, the results showed that maximum nutrient digestibility values were found at $10 \%$ replacement level and started decreasing from $20 \%$ level of MOLM replacement.

Table V.- Composition of nutrients (\%) in feces of $L$. rohita fingerlings fed varying levels of MOLM based diets.

\begin{tabular}{lccc}
\hline Diets & $\begin{array}{c}\text { Crude protein } \\
(\mathbf{\%})\end{array}$ & $\begin{array}{c}\text { Crude fat } \\
(\mathbf{\%})\end{array}$ & $\begin{array}{c}\text { Gross energy } \\
(\mathbf{\%})\end{array}$ \\
\hline $\begin{array}{l}\text { Test diet-I } \\
\text { (Control) }\end{array}$ & $14.22^{\mathrm{b}}$ & $2.84^{\mathrm{c}}$ & $2.13^{\mathrm{b}}$ \\
$\begin{array}{l}\text { Test diet-II } \\
\text { MOLM (10\%) }\end{array}$ & $9.01^{\mathrm{a}}$ & $1.78^{\mathrm{a}}$ & $1.46^{\mathrm{a}}$ \\
$\begin{array}{l}\text { Test diet-III } \\
\text { MOLM }(20 \%)\end{array}$ & $12.47^{\mathrm{b}}$ & $2.23^{\mathrm{b}}$ & $1.73^{\mathrm{a}}$ \\
$\begin{array}{l}\text { Test diet-IV } \\
\text { MOLM (30\%) }\end{array}$ & $17.14^{\mathrm{c}}$ & $3.25^{\mathrm{d}}$ & $2.33^{\mathrm{bc}}$ \\
$\begin{array}{l}\text { Test diet-V } \\
\text { MOLM (40\%) }\end{array}$ & $19.15^{\mathrm{c}}$ & $3.85^{\mathrm{e}}$ & $2.69^{\mathrm{c}}$ \\
$\begin{array}{l}\text { PSE } \\
\text { p-Value }\end{array}$ & 0.54908612 & 0.2092845 & 0.07821615 \\
\hline
\end{tabular}

PSE, pooled standard error; Means within rows having different superscripts are significantly different at $\mathrm{P}<0.05$. Data are means of three replicates.

Table VI.- Apparent nutrient digestibility (\%) of $L$. rohita fingerlings fed varying levels of MOLM based diets.

\begin{tabular}{lccc}
\hline Diets & $\begin{array}{c}\text { Crude protein } \\
(\%)\end{array}$ & $\begin{array}{c}\text { Crude fat } \\
(\mathbf{\%})\end{array}$ & $\begin{array}{c}\text { Gross energy } \\
(\mathbf{\%})\end{array}$ \\
\hline $\begin{array}{l}\text { Test diet-I } \\
\text { (Control) }\end{array}$ & $59.74^{\mathrm{bc}}$ & $59.56^{\mathrm{b}}$ & $57.88^{\mathrm{bc}}$ \\
$\begin{array}{l}\text { Test diet-II } \\
\text { MOLM (10\%) }\end{array}$ & $74.03^{\mathrm{a}}$ & $73.54^{\mathrm{a}}$ & $68.40^{\mathrm{a}}$ \\
$\begin{array}{l}\text { Test diet-III } \\
\text { MOLM }(20 \%)\end{array}$ & $64.93^{\mathrm{ab}}$ & $67.65^{\mathrm{a}}$ & $63.30^{\mathrm{ab}}$ \\
$\begin{array}{l}\text { Test diet-IV } \\
\text { MOLM (30\%) }\end{array}$ & $53.06^{\mathrm{cd}}$ & $54.26^{\mathrm{b}}$ & $51.78^{\mathrm{c}}$ \\
$\begin{array}{l}\text { Test diet-V } \\
\text { MOLM }(40 \%)\end{array}$ & $47.23^{\mathrm{d}}$ & $45.32^{\mathrm{c}}$ & $44.21^{\mathrm{d}}$ \\
$\begin{array}{l}\text { PSE } \\
\text { p-Value }\end{array}$ & 2.11654065 & 1.38465559 & 1.45755732 \\
\hline
\end{tabular}

PSE, pooled standard error; Means within rows having different superscripts are significantly different at $\mathrm{P}<0.05$. Data are means of three replicates.

\section{DISCUSSION}

Fish meal is being used as a major feed ingredient for fish in history. But limited supply as well as high cost makes it necessary to search for an alternative protein source. Nowadays, plant sources are being used to replace the fish meal, either partially or totally. Practical fish feed is an area of focus in aquaculture nutrition research recently (Siddhuraju and Becker, 2003). In recent times, mostly research is being focused on the inclusion of unconventional feed stuffs such as $M$. oleifera as a substitute of fish meal in fish feeds (Richter et al., 2003; Abo-State et al., 2014). Moringa leaf has been studied extensively as an alternative source of protein in fish diet and seems to be an unbeatable protein source. Moringaleaf meal can partly replace the conventional diets without causing any decline in growth performance of Oreochromis niloticus L. (Afuang et al., 2003; Richter et al., 2003).

In the present study mean weight gain in the diets $\mathrm{I}-\mathrm{V}$ is showing that all formulated diets are nutritionally adequate. Fish fed treatment II (10\% MOLM replacement) had the highest weight gain $350 \%$ as compared to control diet ( $0 \%$ MOLM) 263\%. The highest/poor FCR was recorded in treatment- $\mathrm{V}$ with the value of 1.70 while the lowest/best value (1.33) was observed in treatment II (10\% MOLM) that was significantly different from control as well as other diets. These results are similar to those of Richter et al. (2003) who found positive effects on growth performance when fish was fed on MOLM based diet at $10 \%$ replacement level. Furthermore, Kakengi et al. (2007) suggested that the lower levels of MOLM inclusion in diets are suitable for mono-gastric animals. They explained that higher levels of MOLM are not good for fish growth performance. In present study higher feed intake was recorded in diet-II (10\% MOLM) whereas the lowest value was found at diet- $\mathrm{V}$ showing that higher inclusion level of MOLM resulted in reduced feed intake and poor FCR value. Similarly, in a study, Bello and Nzeh (2013) found that Clarias gariepinus fed with $0 \%, 10 \%, 20 \%$, $30 \%, 40 \%$ and $50 \%$ MOLM diet showed best FCR in 10\% MOLM based diet. They argued that inclusion of MOLM at higher levels in the fish feed resulted in a decrease in FCR. On the other hand, Afung et al. (2003) reported that MOLM could be replaced up to $30 \%$ of fish meal without any negative effect on growth performance. Abo-State et al. (2014) reported that the growth performance of fish fed with 10 and $12 \%$ MOLM based diets was inferior to those of fish fed with the $8 \%$ MOLM. Their results infer that raw Moringa leaves meal might be used up to the level of $8 \%$ of dietary protein in Nile tilapia (Oreochromis niloticus) fingerlings diets without producing any negative effect on growth performance, nutrient utilization and carcass 
composition

In the present study we observed the highest nutrient digestibility such as crude protein $(74.03 \%)$, crude fat $(73.54 \%)$ and gross energy $(68.40 \%)$ at $10 \%$ inclusion level of MOLM. But at higher levels of MOLM based diets decreased the utilization of nutrients in fish body. The decreased body nutrient contents were probably due to poor feed intake in diets at higher levels of MOLM, which resulted in starvation and in turn led to mobilization of body lipid reserves to meet energy requirements for vital body functions (Madalla et al., 2013). Bello and Nzeh (2013) also reported that the addition of MOLM at $10 \%$ level in fish feeds showed highest protein efficiency ratio (PER). Similarly, Mehdi et al. (2016) conducted a study on MOLM replacement at 0, 10, 20 and 30\% level. They found highest digestibility of crude protein at $10 \%$ in $L$. rohita fingerlings. Similar results were also observed in a study when Asian sea bass, Lates calcarifer fingerlings were fed on $10 \%$ inclusion of MOLM in fish feed and showed higher crude protein level in body (Erlinda and Naret, 2014). Abo-State et al. (2014) observed higher protein efficiency ratio (PER) in Nile tilapia fingerlings (Oreochromis niloticus) fed on $8 \%$ replacement of fishmeal with MOLM in fish feed.

In our results it was noted that MOLM is a good alternative plant protein source feed ingredient for fish fingerlings at lower inclusion levels whereas the nutrient utilization by fish decreases as MOLM increases to higher levels (30\% and 40\%). Lower levels of MOLM replacement in fish diets are suitable for monogastric animals whereas higher levels of MOLM show adverse effects on nutrient digestibility (Kakengi et al., 2007). The presence of anti-nutritional factors such as saponins and phytate may also have contributed to inhibit pancreatic lipase activity and hence delayed intestinal absorption of dietary nutrients (Han et al., 2000).

The results of present study showed that minimum amount of nutrients such as crude protein, crude fat and apparent gross energy was discharged through feces at $10 \%$ and $20 \%$ levels of MOLM replacement. Similarly, in a study, tilapia fingerlings were fed on raw Moringa leaf meal based diets and it was noted that $10 \%$ replacement of fishmeal with MOLM diet did not cause any adverse effect on nutrients discharge (Richter et al., 2003). Ochang et al. (2015) observed a significant decrease in nutrient utilization by fish fed on 20\% MOLM based diet. Due to leaching of soluble nutrients, reduction of most nutrients was observed when higher levels of moringa leaves were used in fish diets.

In the current study, the ADC of crude lipid (68\%) was low as compared to the routinely reported range of 85 95\% (NRC, 1993). This decrease may be due to significant amounts of indigestible wax which are present in the lipid fraction of MOLM (Afuang et al., 2003). Our results demonstrated that gross energy digestibility was highest at $10 \%$ level of MOLM and it was significantly different from values observed on other diets. According to Madalla et al. (2012), highest gross energy digestibility value (77\%) was observed when Nile tilapia fed on MOLM based diet and significantly different from the values of reference diet. On contradiction, Dongmeza et al. (2006) found the highest gross energy values on reference diet instead of Moringa by-products based diets. Ritcher et al. (2003) also found highest value of gross energy in fish body at 10\% MOLM replacement level based diet whereas the gross energy values decreases with the $20 \%$ and $30 \%$ inclusion of MOLM levels.

\section{CONCLUSION}

According to our results it can be concluded that costly fish meal can be replaced with cost effective plant by-product i.e. Moringa oleifera leaf meal upto $10 \%$ without any adverse effects on fish growth performance and nutrient digestibility of $L$. rohita fingerlings. It showed that $10 \%$ MOLM inclusion is suitable for maximum increase in fish growth performance and highest nutrient digestibility.

\section{Statement of conflict of interest}

Authors have declared no conflict of interest.

\section{REFERENCES}

Abo-State, H., Hammouda, Y., El-Nadi, A. and AboZaid, H., 2014. Evaluation of Feeding raw Moringa (Moringa oleifera Lam.) leaves meal in Nile tilapia fingerlings (Oreochromis niloticus) diets. Global Vet., 13: 105-111.

Afuang, W., Siddhuraju, P. and Becker, K., 2003. Comparative nutritional evaluation of raw, methanol extracted residues and methanol extracts of moringa (Moringa oleifera Lam.) leaves on growth performance and feed utilization in Nile tilapia (Oreochromis niloticus L.). Aquacult. Res., 34: 1147-1159. https://doi.org/10.1046/j.13652109.2003.00920.x

Allan, G.L. and Rowland, S.J., 1992. Development of an experimental diet for silver perch (Bidynus bidyanus). Austasia Aquacult., 6: 39-40.

AOAC, 1995. Official methods of analysis, $15^{\text {th }}$ Ed. Association of Official Analytical chemists, Washington, DC, USA, pp. 1094.

Ayotunde, E.O., Offem, B.O. and Bekeh, A.F., 2011. 
Toxicity of Carica papaya Linn: Haematological and piscicidal effect on adult catfish (Clarias gariepinus). J. Fish. Aqua. Sci., 6: 291-308.

Bello, N.O. and Nzeh, G.C., 2013. Effects of varying levels of Moringa oleifera leaf meal diet on growth performance, hematological indices and biochemical enzymes of African catfish Clarias gariepinus (Burchell 1822). Elixir Aquacult., 57: 14459-14466.

Bosch, C.H., 2004. Moringa oleifera Lam. In: PROTA (Plant resources of tropical Africa / Ressources végétales de l'Afrique tropicale) (eds. G.J.H. Grubben and O.A. Denton). Wageningen, Netherlands.

Bostock, J., McAndrew, B., Richards, R., Jauncey, K., Telfer, T., Lorenzen, K., Little, D., Ross, L., Handisyde, N., Gatward, I. and Corner, R., 2010. Aquaculture: Global status and trends. Philos. Trans. R. Soc. London Ser. B., 365: 2897-2912. https://doi.org/10.1098/rstb.2010.0170

Bundit, Y. and Toshiro, M., 2012. Replacing Moringa leaf (Moringa oleifera) partially by protein Replacement in soybean meal of Fancy carp (Cyprinus carpio). Department of Fisheries, Faculty of Agriculture, KhonKaen University, KhonKaen 5 40002, Thailand.

Chiseva, S., 2006. The growth rates and feed conversion ratios of fry fed conventional fry diets and Moringa oleifera supplemented diets. B.Sc. dissertation, Bindura University of Science Education, Zimbabwe.

Diana, J.S., Egna, H.S., Chopin, T., Peterson, M.S., Cao, L., Pomeroy, R., Verdegem, M., Slack, W.T., Bondad-Reantaso, M.G. and Cabello, F., 2013. Responsible aquaculture in 2050: valuing local conditions and human innovations will be key to success. Bioscience, 63: 255-262.

Divakaran, S., Leonard, G.O. and Lan, P.F., 2002. Note on the methods for determination of chromic oxide in shrimp feeds. J. Agric. Fd. Chem., 50: 464-467. https://doi.org/10.1021/jf011112s

Dongmeza, E., Siddhuraju, P., Francis, G. and Becker, K., 2006. Effects of dehydrated methanol extracts of moringa (Moringa oleifera Lam.) leaves and three of its fractions on growth performance and feed nutrient assimilation in Nile tilapia (Oreochromis niloticus). Aquaculture, 261: 407-422. https://doi. org/10.1016/j.aquaculture.2006.08.006

Erlinda, S. and Naret, G., 2014. Utilization of Moringa oleifera leaf meals as plant protein sources at different inclusion levels in fish meal based diets fed to Lates calcarifer. Animal. Biol. Anim. Husband.
Bioflux., 6: 158-167.

Francis, G., Makkar, H.P.S. and Becker, K., 2001. Anti-nutritional factors present in plant derived alternative fish feed ingredients and their effects in fish. Aquaculture, 199: 197-227. https://doi. org/10.1016/S0044-8486(01)00526-9

Gatlin III, D.M., Barrows, F.T., Brown, P., Dabrowski, K., Gaylord, T.G., Hardy, R.W., Herman, E., Hu, G., Krogdahl, A., Nelson, R., Overturf, K., Rust, M., Sealey, W., Skonberg, D., Souza, E.J., Stone, D., Wilson, R. and Wurtele, E., 2007. Expanding the utilization of sustainable plant products in aqua feeds: a review. Aquat. Res., 38: 551-579. https:// doi.org/10.1111/j.1365-2109.2007.01704.x

Grubben, G.J.H. and Denton, O.A., 2004. Plant resources of tropical Africa 2. Vegetables. PROTA Foundation, Wageningen, Netherlands/Backhuys Publishers, Leiden, Netherlands/CTA, Wageningen, Netherlands.

Han, L.K., Xu, B.J., Kimura, Y., Zheng, Y. and Okuda, H., 2000. Platycodi radix affects lipid metabolism in mice with high fat diet-induced obesity. J. Nutr., 11: 2760-2764. https://doi.org/10.1093/jn/130.11.2760

Hussain, S.M., Javed, M., Javid, A., Javid, T. and Hussain, N., 2011. Growth responses of Catla catla, L. rohita and Cirrhina mrigala during chronic exposure of iron. Pak. J. agric. Sci., 48: 225-230.

Hussain, S.M., Afzal, M., Javid, A., Hussain, A.I., Ali, Q., Mustafa, I., Chatha, S.A.S., Shah, S.Z.H., Hussain, M. and Ullah, M.I., 2015. Efficacy of phytase supplementation on growth performance and mineral digestibility of $L$. rohita fingerlings fed on cottonseed meal based diet. Pakistan J. Zool., 47: 699-709.

Hussain, S.M., Afzal, M., Nasir, S., Javid, A., Makhdoom, S.M., Jabeen, F., Azmat, H., Hussain, M. and Shah, S.Z.H., 2016. Efficacy of phytase supplementation in improving mineral digestibility in Labeo rohita fingerlings fed on canola mealbased diets. Iran. J. Fish. Sci., 15: 645-661.

Kakengi, A.M.V., Kaijage, J.T., Sarwatt, S.V., Mutayoba, S.K., Shem, M.N. and Fujihara, T., 2007. Effect of Moringa oleifera leaf meal as a substitute for sunflower seed meal on performance of laying hens in Tanzania. Livest. Res. Rural Develop., 19: 120.

Lovell, R.T., 1989. Nutrition and feeding of fish. Van Nostrand-Reinhold, New York, pp. 260. https://doi. org/10.1007/978-1-4757-1174-5

Lyimo, M., Mugula, J. and Elias, T., 1992. Nutritive composition of broth from selected bean varieties cooked for various periods. J. Sci. Fd. Agric., 4: 535-539. https://doi.org/10.1002/jsfa.2740580413 
Madalla, N., Agbo, N.W. and Jauncey, K., 2013. Evaluation of aqueous extracted Moringa leaf meal as a protein source for Nile tilapia juveniles Prot. Tanzania. Agric. Sci., 12: 53-64.

Makkar, H.P.S. and Becker, K., 1996. Nutritional value and antinutritional components of whole and ethanol extracted Moringa oleifera leaves. Anim. Feed Sci. Tech., 63: 211-228. https://doi. org/10.1016/S0377-8401(96)01023-1

Mehdi, H., Khan, N., Iqbal, J.K., Rasool, F., Chaudhry, M.S. and Khan, K.J., 2016. Effect of Moringa oleifera meal on the growth, body composition and nutrient digestibility of L. rohita. Int. J. Biosci., 8: 11-17. https://doi.org/10.12692/ijb/8.4.11-17

Naylor, R.L., Goldburg, R.J., Primavera, J.H., Kautsky, N., Beveridge, M.C.M., Clay, J., Folke, C., Lubchenco, J., Mooney, H. and Troell, M., 2000. Effect of aquaculture on world fish supplies. Nature, 405: 1017-1024. https://doi.org/10.1038/35016500

Naylor, R.L., Hardy, R.W., Bureau, D.P., Chiu, A., Elliott, M., Farrell, A.P., Forster, A.P., Gatlin, I., Goldburg, D.M., Hua, R.J. and Nichols, P.D., 2009. Feeding aquaculture in an era of finite resources. Proc. natl. Acad. Sci., 106: 15103-15110. https:// doi.org/10.1073/pnas.0905235106

Nouala, F.S., Akinbamijo, O.O., Adewumi, A., Hoffman S., Muetzel, S. and Becker, K., 2006. The influence of Moringa olifera leaves as substitute to conventional concentrate on the in vitro gas production and digestibility of groundnut hay. Livest. Res. Rural Develop., 18: 121. http://www. 1rrd.org/lrrd18/9/noua18121.htm

NRC, 1993. Nutrient requirements of fish 114. National Research Council, National Academy Press, Washington DC.

Ochang, S.N., Peter, B.M., Ugbor, O.N. and Egor, A., 2015. Effect of diets with Moringa leaf meal on growth, carcass composition and haematology of Clarias gariepinus. Int. J. Fish. Aqua. Stud., 3: 397401.

Olsen, R.L. and Hasan, M.R., 2012. A limited supply of fishmeal: Impact on future increases in global aquaculture production. Trends Fd. Sci. Tech., 27: 120-128. https://doi.org/10.1016/j.tifs.2012.01.008

Rana, K.J., Siriwardena, S. and Hasan, M.R., 2009. Impact of rising feed ingredient prices on aquafeeds and aquaculture production. In: FAO fisheries and aquaculture technical paper, Vol. 541. FAO, Rome.

Richter, N., Siddhuraju, P. and Becker, K., 2003. Evaluation of nutritional quality of moringa (Moringa oleifera Lam.) leaves as an alternative protein source for Nile tilapia (Oreochromis niloticus L.). Aquaculture, 217: 599-611. https:// doi.org/10.1016/S0044-8486(02)00497-0

Rowland, S.J. and Ingram, B.A., 1991. Diseases of Australian native fishes. In: Fisheries bulletin 4 (ed. M. Stevens). NSW Fisheries, Sydney, Australia.

Siddhuraju, P. and Becker, K., 2003. Antioxidant properties of various solvent extracts of total phenolic constituents from three different agroclimatic origins of drumstick tree (Moringa oleifera Lam.). J. Agric. Fd. Chem., 15: 2144-2155. https:// doi.org/10.1021/jf020444+

Snedecor, G.W. and Cochran, W.G., 1991. Statistical methods, $8^{\text {th }}$ Ed. Iowa State University Press, USA, pp. 503.

Soliva, C.R., Kreuzer, M., Foidl, N., Foidl, G., Machmuller, A. and Hess, H.D., 2005. Feeding value of whole and extracted Moringa oleifera leaves for ruminants and their effects on ruminal fermentation in vitro. Anim. Feed Sci. Tech., 118: 47-62. https:// doi.org/10.1016/j.anifeedsci.2004.10.005

Steel, R.G.D., Torrie, J.H. and Dickey, D.A., 1996. Principles and procedures of statistics, $3^{\text {rd }} \mathrm{Ed}$. McGraw Hill International Book Co. Inc., New York, USA, pp. 336-352.

Tacon, A. and Metian, M., 2013. Fish matters: Importance of aquatic foods in human nutrition and global food supply. Rev. Fish. Sci., 21: 22-38. https://doi.org/10.1080/10641262.2012.753405

Tacon, A.G.J., Hasan, M.R. and Subasinghe, R.P., 2006. Use of fishery resources as feed inputs to aquaculture development: Trends and policy implications. In: FAO fisheries circular, Vol. 1018. FAO, Rome.

Tagwireyi, T., Mupangwa, J.F., Jepsen, J. and Mwera, P., 2014. The effect of feeding heat treated Moringa oleifera (Lam) leaf meal on the growth performance of Oreochromis niloticus (Lam) fry. UNISWA J. Agric., 17: 14-20. http://www.appropriatetech.net/ files/3rd_ICAT_Proceedings_Part_5.pdf 